\title{
Preimplantation genetic diagnosis for cystic fibrosis: a case report
}

\author{
Diagnóstico genético pré-implantacional na fibrose cística: relato de caso
}

\author{
Maria Cristina Santoro Biazotti ${ }^{1}$, Walter Pinto Junior ${ }^{2}$, Maria Cecília Romano Maciel de Albuquerque ${ }^{3}$, \\ Litsuko Shimabukuro Fujihara ${ }^{4}$, Cláudia Haru Suganuma ${ }^{5}$, Renata Bednar Reigota ${ }^{2}$, Carmen Sílvia Bertuzzo $^{2}$
}

\begin{abstract}
Cystic fibrosis is an autosomal recessive disorder caused by mutations in the cystic fibrosis transmembrane conductance regulator gene. This disorder produces a variable phenotype including lung disease, pancreatic insufficiency, and meconium ileus plus bilateral agenesis of the vas deferens causing obstructive azoospermia and male infertility. Preimplantation genetic diagnosis is an alternative that allows identification of embryos affected by this or other genetic diseases. We report a case of couple with cystic fibrosis; the woman had the I148 T mutation and the man had the Delta F508 gene mutation. The couple underwent in vitro fertilization, associated with preimplantation genetic diagnosis, and with subsequent selection of healthy embryos for uterine transfer. The result was an uneventful pregnancy and delivery of a healthy male baby.
\end{abstract}

Keywords: Cystic fibrosis; Fertilization in vitro; Preimplantation genetic diagnosis; Case reports

\section{RESUMO}

A fibrose cística é uma doença autossômica recessiva causada por mutações no gene regulador de condutância transmembrana na fibrose cística. Produz fenótipo variável, incluindo doença pulmonar, insuficiência pancreática, íleo meconial, além de agenesia bilateral dos ductos deferentes, causando azoospermia obstrutiva e infertilidade masculina. 0 diagnóstico genético pré-implantacional é uma alternativa diagnóstica, que permite identificar embriões portadores de fibrose cística e outras doenças genéticas. Relatamos 0 caso de um casal portador de fibrose cística, sendo a mulher portadora da mutação I148 T e o homem da mutação gênica Delta F508. 0 casal foi submetido a técnicas de fertilização in vitro associadas ao diagnóstico genético pré-implantacional, com consequente seleção de embriões saudáveis, que foram transferidos para 0 útero, resultando em gravidez sem intercorrências e com feto saudável, do sexo masculino.

Descritores: Fibrose cística; Fertilização in vitro; Diagnóstico genético pré-implantação; Relatos de casos

\section{INTRODUCTION}

Assisted reproductive techniques progress each day as a result of improvements in laboratory technology, gametes and embryos culture. The introduction of new drugs to induce ovulation and the enhancement of cryopreservation techniques of gametes and embryos are part of this development.

These advances may benefit cystic fibrosis carrier couples or those with previous genetic disease with in vitro fertilization (IVF) associated to preimplantation genetic diagnosis (PGD), enabling the selection of healthy embryos before intrauterine transference. ${ }^{(1)}$

\section{Preimplantation genetic diagnosis}

The PGD was developed with the aim to provide alternatives for prenatal diagnosis in couples with risk to transmit genetic disease to their offspring. This procedure can be useful in cases of disease associated to sex, chromosome anomalies and disorders involving a single gene. ${ }^{(1)}$

\footnotetext{
Hospital Israelita Albert Einstein, São Paulo, SP, Brazil.

2 Universidade Estadual de Campinas, Campinas, SP, Brazil.

${ }^{3}$ Centro Cochrane do Brasil, São Paulo, SP, Brazil.

${ }^{4}$ Centro de Reprodução Humana Fertivitro, São Paulo, SP, Brazil.

${ }^{5}$ Sêmion, Centro de Medicina Reprodutiva, Campinas, SP, Brazil.

Corresponding author: Maria Cristina Santoro Biazotti - Avenida Albert Einstein, $627 / 701$ - Morumbi -Zip Code: 05652-900 - São Paulo, SP, Brazil - Phone: (55 11) 2151-9205 - E-mail: biazotti@biazotti.com Received on: Mar 21, 2013 - Accepted on: Feb 25, 2014

DOI: 10.1590/S1679-45082015RC2738
} 
During PGD, couples must undergone IVF, even in cases without indication to conduct this technique (Figure 1). To reduce risks of contamination by parental cells during IVF, it is recommended to use intracytoplasmic sperm injection (ICSI). ${ }^{(2)}$ In the event of fertilization, embryos remain in culture until that one or more cells can be removal and submitted for genetic diagnosis. ${ }^{(1)}$

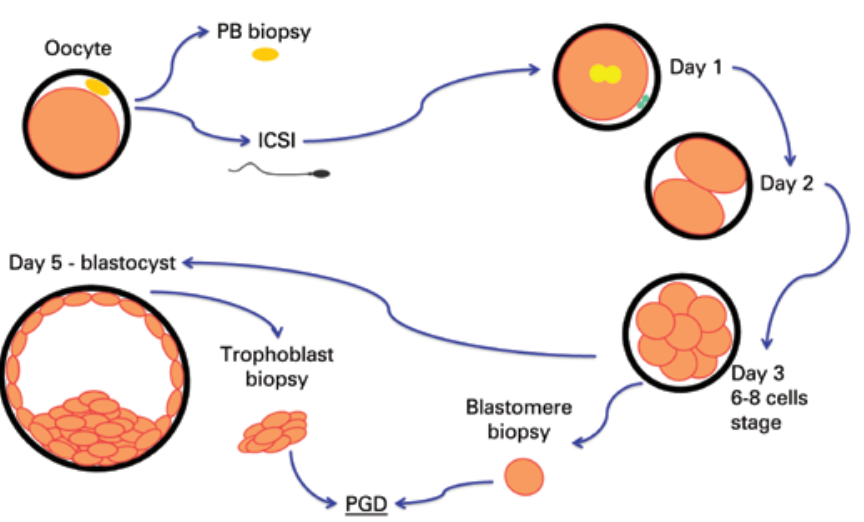

ICSI: intra-citoplasmic sperm injection; PGD: preimplantation genetic diagnosis.

Figure 1. Preimplantation genetic diagnosis

For PGD, we used techniques based on the polymerase chain reaction (PCR) and molecular cytogenetics. After long-term use, the technique of fluorescent in situ hybridization (FISH) has been substituted by arraycomparative genomic hybridization $(\mathrm{aCGH}),{ }^{(3,4)}$ which analysis specific amplifications and deletions of the genome. This latter enables the detection of gains and losses of genetic material in specific high resolution regions of genome (10 to 100 times higher than traditional techniques), ${ }^{(5)}$ depending on the analysis platform used. In addition, aCGH provide a more accurate assessment of chromosomal anomalies and gene deletions or rearrangements than FISH.

\section{Biopsy of embryos}

Embryo biopsy involves removal of one or more cells from the early preimplantation embryo for subsequent genetic investigation. The first case of PGD in human was reported by Handyside et al. ${ }^{(6)}$

After ICSI of oocytes, embryos are cultured for 3rd days, or may be cultured until the blastocyst stage (5th/6th day of culture) to be, after that, submitted to biopsy, without negatively affecting implementation or gestational development. ${ }^{(6)}$ The biopsy is often done on the 3rd day of embryonic development (staging six to eight cells) by the removal of one or two blastomeres from each embryo ${ }^{(7)}$ (Figure 2). One of the advantages of postponing biopsy of embryos until the blastocyst stage, is the possibility of obtaining the larger number of cells (trophoderm) for genetic analysis, therefore, increasing the DNA copy number to improve accuracy of diagnosis. ${ }^{(8)}$

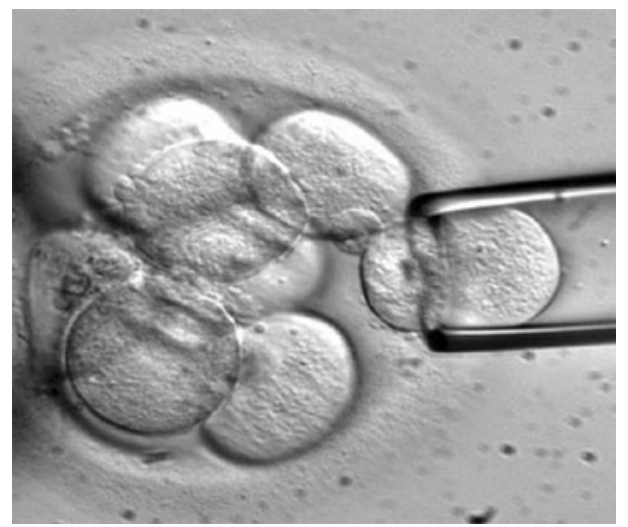

Figure 2. Biopsy

\section{Cystic fibrosis}

Cystic fibrosis (CF) is an autosomal recessive disorder caused by mutations in cystic fibrosis transmembrane conductance regulator (CFTR) gene that affects 1 of each 2,500 newborns. ${ }^{(9)}$ This gene codifies a protein expressed in apical membrane of exocrine epithelia cells. ${ }^{(10)}$ Mutations in CFTR gene produce an variable phenotype, including pulmonary disease, pancreatic disease, meconium ileus ${ }^{(11)}$ and they are also involved in bilateral agenesis of the vas deferens, causing obstructive azoospermia and male infertility ${ }^{(12)}$ (Figure 3).

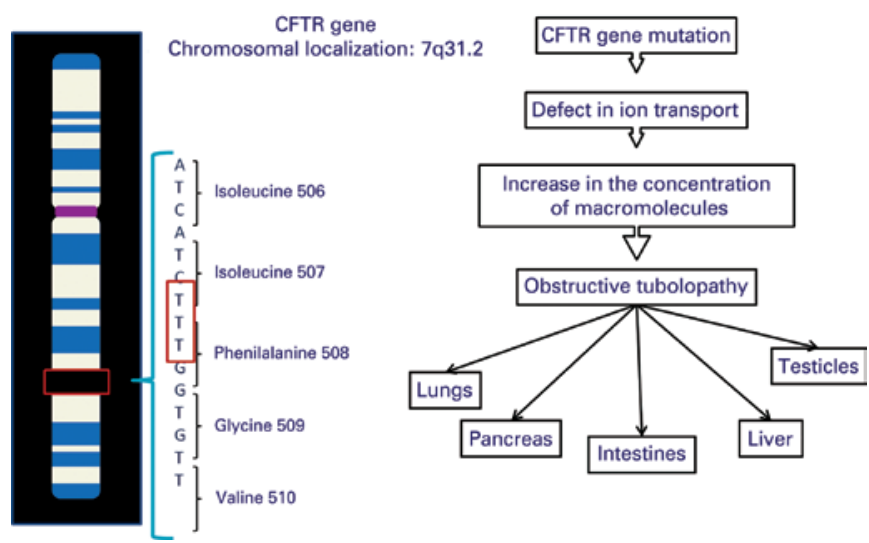

Figure 3. Cystic fibrosis

\section{CASE REPORT}

We report a case of 33-year-old woman who did not have children and was first evaluated in March 25, 2004 
due to difficulties in becoming pregnant for 2 years. She reported menarche at 11 years of age, regular menstrual cycle and a previous maternal history of breast cancer. Her transvaginal ultrasonography, showed a left paratubal cyst and suggestive imaging of right dermoid cyst measuring $16.0 \times 12.0 \mathrm{~mm}$, which were stable for 12 months. Laboratorial exams and investigations for fungi and bacterial in vaginal secretions were normal. The patient had the I148 mutation in CF.

The patient was married for 12 years. Her husband was 33-years-old and had severe oligospermia and varicocele. After he underwent surgical correction, he progressed with improvement of seminal parameters, which sperm concentration increased from 0.75 million $/ \mathrm{mL}$ to $5.48 \mathrm{million} / \mathrm{mL}$. In addition, he had Delta F508 mutation in $\mathrm{CF}$.

In September 2004, the patient underwent IVF/ICSI and seven embryos were obtained. Of these, three were transferred to the patient and four were frozen. Her pregnancy test was positive in October 22, 2004 and the transvaginal ultrasonography showed one gestational sac compatible at 5 weeks of gestation. In December 10 , at 11 weeks of gestation, the patient underwent a chorionic villus biopsy that confirmed a male fetus. To assess the Delta F508 mutation, we used the PCR and $12 \%$ polyacrylamide gel electrophoresis. The I148T mutation was investigated using PCR with primers involving exon 4. Subsequently, we conduct an enzymatic digestion with Bsrl enzyme. These tests showed that the embryo had the CF mutation.

Later, the patient progressed to miscarriage and underwent a uterine curettage in May 2005. After that, she was not followed-up for 5 months.

We observed that the couple had TUB18 and KM19 polymorphisms, which enabled the identification of mutant alleles in future gestations, thereby increasing the possibility of detecting an affected embryo.

In April 2006, the patient underwent a hysteroscopy for uterine septum resection, secondary to previous curettage. The use of GnRH analogs, antibiotics and polivitaminic was reinstated in May 2006. However, there was a poor response to hypothalamic/hypophysary inhibitory factor.

In the next stage, we opted use her natural cycle by detecting follicles of $19.0 \mathrm{~mm}$ of diameter in the right ovary and trilaminar endometrium with $10.0 \mathrm{~mm}$ in thickeness detected by transvaginal ultrasonography. This was done August 31, 2006.

Four embryos previously frozen were biopsied using a laser guided technique for opening of zona pellucida, and the blastomeres were genetically assessed. There was no amplifications of primers in the first embryo, which prevented investigation for mutations. The second embryo blastomere had both mutations and, was therefore, a CF carrier. The third embryo blastomere had only the I148T mutation and in the fourth embryo there were no mutations found. The third and fourth embryos were transferred to the patients uterus on September 5, 2006. An echography done in November 6, 2006 showed a gestation compatible with 11 weeks and 5 days by biometry. The fetus presented nuchal translucency within normal ranges. In May 10 2007, the patient underwent cesarean section and gave birth to a male baby weighing 3,320g and with an Apgar score of $8 / 10$ without intercurrences. She breastfed her baby for 2 months and returned to clinic visit 11 months after delivery. The child's laboratorial exams showed polyglobulie and eosinophilia without other changes or complaints.

\section{DISCUSSION}

In recessive autosomal diseases, each parent of the child affected has one copy of a mutated allele. In each pregnancy, the possibility of the child born with the disease is $25 \%$. Those with the disease are asymptomatic and couples become aware of the problem only when they experience this in their children, on his/her family or during previous investigations. ${ }^{(13)}$ For this reason, the PGD associated with IVF/ICSI in a risk situation, seems to be the only way to avoid recurrence. ${ }^{(14)}$

Taylor et al. concluded that laser did not influence biopsy and nor affected the development of the embryo. ${ }^{(15)}$ A study by Keymolen et al. conducted for 11 years at a Medical Genetic Center in Belgium, reported PGD in embryos from 47 couples; CF was the most common indication of these procedures (55\% of cases). In their study 461 embryos were submitted to biopsy and among 25 newborns, no child was diagnosed with $\mathrm{CF}^{(16)}$

We report a case of PGD that resulted in the birth of healthy child whose parents had a risk of transmiting CF. The mother had the I148T mutation in CF and the father had the Delta F508 mutation for the same disease. The couple underwent IVF/ICSI procedures, vitrification and devistrification of embryos, PGD and embryo transfer. The pregnancy was confirmed without intercurrences, and male baby was delivery by cesarean section.

The use of PGD was efficient in detecting CF in the embryos assessed. This was a positive experience and encourages a more frequent use of this technique. In addition, our findings may stimulate the development of PGD protocols for several other genetic disorders. 


\section{REFERENCES}

1. Harper J. Preimplantation Genetic Diagnosis. 2a ed. Cambridge: Cambridge University Press; 2009.

2. ESHRE Capri Workshop Group. Intracytoplasmic sperm injection (ICSI) in 2006: evidence and evolution. Hum Reprod Update. 2007;13(6):515-26.

3. Simpson JL, Rechtsky S, Kuliev A. Next-generation sequencing for preimplantation genetic diagnosis. Fertil Steril. 2013;99(5):1203-4.

4. Martín J, Cervero A, Mir P, Martinez-Conejero JA, Pellicer A, Simón C. The impact of next-generation sequencing technology on preimplantation genetic diagnosis and screening. Fertil Steril. 2013;99(4):1054-61. Review. Erratum in: Fertil Steril. 2013;99(6):1798. Conejero Martinez, Jose Antonio [corrected to Martinez-Conejero, Jose Antonio].

5. Theisen A. Microarray-based comparative genomic hybridization (aCGH). Nature Educ. 2008;1(1):45.

6. Handyside AH, Kontogianni EH, Hardy K, Winston RM. Pregnancies from biopsied human preimplantation embryos sexed by Y-specific DNA amplification. Nature. 1990;344(6268):768-70.

7. Harper JC, Boelaert K, Geraedts J, Harton G, Kearns WG, Moutou C, et al. ESHRE PGD Consortium data collection V: cycles from January to December 2002 with pregnancy follow-up to October 2003. Hum Reprod. 2006;21(1):3-21.

8. Kokkali G, Traeger-Synodinos J, Vrettou C, Stavrou D, Jones GM, Cram DS, et al. Blastocyst biopsy versus cleveage stage biopsy and blastocyst transfer for preimplantation genetic diagnosis of beta-thalassaemia: a pilot study. Hum Reprod. 2007;22(5):1443-9.
9. Sánchez-García JF, Benet J, Gutiérrez-Mateo C, Luís Séculi J, Monrós E, Navarro J. Multiple mutation analysis of the cystic fibrosis gene in single cells. Mol Hum Reprod. 2005;11(6):463-8.

10. Zielenski J. Genotype and phenotype in cystic fibrosis. Respiration. 2000; 67(2):117-33. Review.

11. Field PD, Martin NJ. CFTR mutation screening in an assisted reproductive clinic. Aust N Z J Obstet Gynaecol. 2011;51(6):536-9.

12. Ghorbel M, Baklouti-Gargouri S, Keskes R, Sellami-Ben Hamida A, FekiChakroun N, Bahloul A, et al. Screening of $\triangle F 508$ mutation and IVS8-poly $T$ polymorphism in CFTR gene in Tunisian infertile men without CBAVD. Andrologia. 2012;44 Suppl 1:376-82.

13. Alberola TM, Bautista-Llácer R, Vendrell X, García-Mengual E, Pardo M, Vila $\mathrm{M}$, et al. Case report: birth of healthy twins after preimplantation genetic diagnosis of propionic acidemia. J Assist Reprod Genet. 2011;28(3):211-6.

14. Ozge A, Safak H, Ebru H, Evrim U, Bilge SE, Leyla O, et al. First successful preimplantation genetic diagnosis of epidermolysis bullosa with pyloric atresia: case study of a novel c.4505-4508insACTC mutation. J Assist Reprod Genet. 2012;29(4):347-52.

15. Taylor TH, Gilchrist JW, Hallowell SV, Hanshew KK, Orris JJ, Glassner MJ, et al. The effects of different laser pulse lengths on the embryo biopsy procedure and embryo development to the blastocyst stage. J Assist Reprod Genet. 2010;27(11):663-7.

16. Keymolen K, Goossens V, De Rycke M, Sermon K, Boelaert K, Bonduelle M, et al. Clinical outcome of preimplantation genetic diagnosis for cystic fibrosis: the Brussels' experience. Eur J Hum Genet. 2007;15(7):752-8. 